\title{
Measuring university-to-work success: development of a new scale
}

\section{Introduction}

The transition from university-to-work is an important step for most new graduates and a topic of interest for researchers and applied practitioners. Young professionals must successfully complete numerous tasks to make this transition, including learning the job, understanding organizational rules and norms, assimilating to the organizational culture, analyzing their fit within the chosen occupation and firm, increasing their competence, developing specialty and team skills, and identifying their long-term goals. Additionally, they need to acquire socio-emotional competencies such as support, autonomy and confidence (Russell, 2005).

During difficult economic times, new graduates often have trouble with entering the labor market and establishing their careers (Koen et al., 2012). These circumstances make it all the more important for researchers to improve theory and interventions for career management in order to help individuals face the university-to-work transition (Loureiro et al., 2013). More insight into factors which promote early career success are needed given the investment to attract and retain young professionals (Van Dierendonck and Van der Gaast, 2013), and because perception of career success can lead to further positive outcomes, such as well-being and improved job performance (Abele et al., 2011).

Career success has traditionally been defined as the accumulated positive jobrelated and psychological outcomes resulting from one's work experiences. These positive outcomes can be extrinsic or intrinsic and could reflect real or perceived accomplishments (Arthur et al., 2005; Judge et al., 1999; Poon et al., 2015; Seibert and Kraimer, 2001). 
Researchers agree that a comprehensive framework for understanding career success must incorporate objective and subjective indicators of the construct (e.g. Arthur et al., 2005; Converse et al., 2012; Hall and Chandler, 2005; Heslin, 2005, Nabi, 1999). Objective career success indicators are directly observable and verifiable, related to society's evaluation of achievement with reference to extrinsic measures. By contrast, subjective career success indicators are based on personal evaluations of success. Theoretically, subjective career success is a multidimensional construct because it can include perceptions of intrinsic and extrinsic outcomes (Nabi, 2001; Ng and Feldman, 2014).

To assess objective career success the majority of prior studies have used selfreported measures of salary and/or promotions (e.g. Boudreau et al., 2001; Day and Allen, 2004; Johnson and Eby, 2011; Seibert and Kraimer, 2001; Wu et al., 2008). These measures are widely used because they are readily accessible and reflect social norms, but are not always straightforward to interpret. To be a valid measure of career success, salary must be evaluated relative to employment field, career stage, and wider economic factors; whereas promotions must be contextualized due to changes in organizational structure where hierarchical positions are not always the most frequent model (Abele et al., 2011).

The most widely-used subjective measures of career success include career satisfaction, measured by Greenhaus et al's. (1990) five-item scale, which includes items such as "I am satisfied with the success I have achieved in my career" (e.g. Colakoglu, 2011; Converse et al., 2012; De Vos et al., 2011), and/or general affectbased measures in which subjects are asked to evaluate the extent they are satisfied with their career accomplishments, current status, income or promotions (Ng and Feldman, 2014). 
It is important to note that because careers are embedded in specific contexts, definitions of career success may need to be dynamic and vary with stage of career as well as professional groups (Abele et al., 2011). However, relatively few studies have attempted to examine systematically career success as a construct including its dimensions (e.g. Dries et al., 2008; Dyke and Murphy, 2006; Hennequin, 2007; Sturges, 1999; Pan and Zhou, 2015; Poon et al., 2015), and career success has been typically assessed by measures that are not sensitive to different career paths, contexts and groups (Mulhall, 2011). Prior research on career success has also been criticized for lack of measurement accuracy (Dries, 2011; Heslin, 2005; Pan and Zhou, 2015).

In summary, most empirical research on career success has adopted one of two approaches. Whereas some researchers use objective measures such as salary or promotions, others use career satisfaction measures or a general questionnaire to assess subjective career success, but tests of validity have been lacking (Abele et al., 2011; Arthur et al., 2005; Pan and Zhou, 2015).

Because the nature of employment is becoming more complex and diverse, it is important for research on career success to broaden its scope. There is a call for more studies that allow individuals to define success in their own words, making possible a more fine-grained analysis of different criteria for career success (Dries et al., 2008; Heslin, 2005). Specifically, it is important to define and operationalize career success across different career stages (Dries et al., 2008), for various occupational categories (Gerber and Saiki, 2010), and for different populations, especially minorities (Heslin, 2003, 2005; Johnson and Eby, 2011). Advances in the conceptualization and operationalization of career success are needed in order to improve the validity of results (Dries et al., 2009). 
To accomplish this goal, researchers have proposed multi-dimensional models that encompass different facets of career success. For example, Sturges (1999) and Poon et al. (2015) identified two underlying dimensions: Intrinsic/subjective success (i.e. related to satisfaction, enjoyable work, happiness, balance, and support) and extrinsic/objective success (i.e. focused on financial rewards, advancement opportunities and promotions). Dyke and Murphy (2006) described four career success outcomes: Balance, relationship, recognition and material success. Hennequin (2007) found three different factors related to career success: Material, psychological and social success.

With the increasing number of new graduates entering the workforce there is a particular need to understand how early career success is shaped. Usually, university-towork success has been associated with employment and adaptation to the work role (Koivisto et al., 2007; Ng and Feldman, 2007). However, most studies with young professionals also use instruments that assess traditional indicators of career success such as salary, promotions and career satisfaction (e.g. Abele and Spurk, 2009; De Vos et al., 2009; Haro et al., 2013; Langowitz et al., 2013; Sauer et al., 2013; Spurk and Abele, 2014; Stumpf, 2014; Van Dierendonck and Van der Gaast, 2013; Waldman and Korbar, 2004).

In recent years, technological advances and economic globalization have had a major impact on how young professionals approach their careers. During times of hiring freezes and widespread layoffs, young persons have started to realize that to be successful in their careers they need to pursue advanced education and learn to adapt to different work situations. For new employees, meaningful work and a sense of accomplishment are just as important as earning a high salary (Levit and Licina, 2011). 
Notably, for this new generation of employees, conceptions of career success are considerably more dynamic than in the past (Hay and Hodgkinson, 2006; Shaw, 2013).

Although new graduates in the process of university-to-work transition are an important category of workers, there have been few studies which have attempted to define and operationalize early career success for this group. Thus the goal of the current study was to develop a new model to measure early career success during the university-to-work transition, and provide evidence for its validity.

To accomplish this goal, our research was divided into three stages: (1) item generation; (2) evaluation of factor structure and test a proposed model with a sample of university graduates from Brazil; and (3) model comparison and evidence for reliability and convergent validity with an independent sample.

\section{Stage 1: Item generation}

The University-to-Work Success Scale (UWSS) was developed to assess personal evaluations of intrinsic and extrinsic career outcomes achieved by individuals who have recently completed undergraduate studies. In the process of developing a new scale, the first task was to create an initial item pool.

Our approach was based on the rationale that early career success during university-to-work transition can be defined through a multiplicity of meanings that emphasize both the extrinsic and intrinsic nature of career success. Items were generated based on deductive and inductive methods (Hinkin, 1998). Initially, we searched in five established journals (Journal of Vocational Behavior, Journal of Career Assessment, The Career Development Quarterly, Journal of Career Development and Journal of Organizational Behavior) for articles concerned with university-to-work transition and career success from 1996 onwards. Our search identified a total of 75 research articles which had in their title the words or phrases 
"career transitions", "transitions", "school-to-work transition", "success" and "career success".

Next, focus groups (Lewis, 1995) were conducted with nine new graduates from two different regions of Brazil, divided randomly into two groups of four and five. The task of these groups was to define university-to-work success in the new graduates' own words. Group interviews were transcribed into a table verbatim, and then were analyzed within- and across-groups independently by two researchers (the first author and a research grant holder). Discourse analysis framework (Potter and Wetherell, 1987; Wetherell and Potter, 1988) and preview literature review were used as a guide to data analyses. To validate the results, a senior professor and expert in vocational psychology (the second author) served as an auditor, verifying the fit of categories and making appropriate adjustments as necessary. Results were organized in terms of eight categories and operationalized by 33 items which represented the new graduates' view of early career success. A summary of the eight categories and respective items is given below:

(1) Career Path Satisfaction. This category described a positive evaluation of work experience after graduation until the achievement of major goals. University-towork success was defined by the opportunities to do what one loves and being able to overcome the adversity of work entry. This intrinsic career outcome was operationalized by four items related to feelings of satisfaction, happiness and fulfillment with the career path. Items included: "I am satisfied with my career after graduation", "I am satisfied with my job", "I feel accomplished in my profession", and "I am working on what I like".

(2) Confidence in Career Future. This category reflected the new graduates' fears in facing the uncertainty inherent to starting a new career. University-to-work 
success is understood as the overcoming of fears and anxieties and increasing confidence in the career future, enabling the construction of positive expectations. This intrinsic career outcome was operationalized by five items that assessed emotional control in relation to feelings of fear and insecurity about the career future. Items included: "I am confident about my professional future", "I have good expectations about my career future", "I have had patience to achieve my career goals," "I feel reassured about my career future", and "I am confident that I will be able to achieve my career goals".

(3) Goal Progress and Career Plans. This category emphasizes new graduates' need to construct a career plan and set goals. Through planning, new graduates can feel successful in the journey through small achievements that will gradually lead to major goals. This intrinsic career outcome was operationalized by three items: "I am happy with my achievements after graduation", "I am involved somehow with my degree area (e.g. employment, job enhancement, post-graduate studies)", and "I have succeeded in achieving the goals I have planned for my career".

(4) Professional Identity Construction. This category referred to the new graduates' need to build and take on a new role in society. This intrinsic career outcome was operationalized by three items that reflect the construction of professional identity. Items were: "I feel like a professional in my field", "I am legally entitled to exercise my profession" and "I am registered in the professional organization of my degree area".

(5) Work Adjustment. This category referred to challenges that new graduates faced entering the world of work, and associated feelings of adapting to the organizational culture and work requirements. This intrinsic career outcome was operationalized by five items: "I am meeting the requirements of the world of work", "I am working on what I have planned", "I am adapted to the requirements and 
responsibilities of my job", "I am adapted to the culture of the workplace (organizational culture)" and "I get into the world of work".

(6) Work in the Degree Area and Income. This category described university-towork success in terms of adherence to social expectations. Participants emphasized that they felt strong pressure to obtain a job in their degree area with a good salary. This extrinsic career outcome was operationalized by four items that assessed the achievement of work in the degree area with good remuneration in accordance with the labor market and peers. Items included: "I am working in the same field of my degree", "I got a job in the same field of my degree", "I get remuneration compatible with the labor market in my area", and "I get a good pay compared to professionals in my field".

(7) Financial Independence. This category referred to economic gains resulting from entering a profession that provides a livelihood and becoming financially independent from one's parents. This extrinsic career outcome was operationalized by four items: "I can pay my bills," "I am able to buy things that interest me", "I am financially independent from my family," and "I am able to live by myself (out of my parents' house)."

(8) Social Recognition by Promotions and Rewards. This category described university-to-work success as good performance that was reflected in promotions and rewards. This extrinsic career outcome was operationalized by five items: "I have been socially recognized by my professional performance", "I was promoted (or rewarded) due to my job performance", "I have been achieving the satisfaction of people who need or make use of the results of my work", "I get compliments on my professional performance" and "I have been referred by people I know to work opportunities".

After item generation, the second task was to demonstrate evidence for content validity. The list of initial 33 items was sent to be reviewed by two judges, Psychology 
$\mathrm{PhDs}$ who were experts in the study of university-to-work transition and measurement construction. The judges were instructed to evaluate each item regarding language clarity, practical and theoretical relevance. In addition, reviewers were asked to contribute suggestions about the items and their contents. Based on their feedback, two items relating to 'professional identity construction' ("I am legally entitled to exercise my profession" and "I am registered in the professional organization of my degree area") were removed because these items were judged to have limited applicability.

Next, the set of 31 items was provided to a group of five recent university graduates (representative of the target audience for the instrument) to assess the clarity and objectivity of items and scale instructions. Respondents completed the instrument and afterwards discussed the clarity of the items with the researchers. Results provided evidence for the items' content validity.

At the end of the item generation process, the preliminary version of UWSS contained a pool of 31 items. The response options were arranged in a 5-point Likert type scale that ranged from 1 - do not agree at all to 5 - agree entirely.

\section{Stage 2: Factor structure and testing a proposed model}

The goal of Stage 2 was to examine the factor structure of the preliminary version of UWSS through exploratory factor analyses, and test a second-order model using confirmatory factor analyses. Specifically, we predicted that an overall higherorder factor representing 'university-to-work success' (UWS), composed of various lower order factors representing different facets of career success, would best describe the data.

\section{Method}

Participants 
The sample included 182 new graduates from public (69.8\%) and private (30.5\%) universities in Brazil. The majority of participants were women (69.2\%). Ages ranged from 21 to 52 years old $(\mathrm{M}=26.1 ; \mathrm{SD}=5.0)$. Regarding ethnicity, $69.8 \%$ were Caucasian, $28 \%$ were Black and $2.2 \%$ were Asian. Concerning time to finish undergraduate studies, $6 \%$ of participants had completed their studies in a range of 1-5 months, $38.5 \%$ between $6-17$ months, $32.4 \%$ between $18-29$ months, and $22.5 \%$ between 30-42 months. In terms of degree major, $41.2 \%$ graduated in Psychology, $20.3 \%$ in Business, $7.7 \%$ in Licentiature courses, $6.6 \%$ in Law, $6.6 \%$ in Engineering, $6.6 \%$ in Health Sciences, and $8.7 \%$ in others.

Procedure

Participants were recruited by convenience sampling. The questionnaire was placed online and participants were directed to a URL link via email or Facebook. Participation was voluntary and anonymity and confidentiality were guaranteed. To be eligible for inclusion, potential participants needed to be (a) new graduates who had recently completed a degree in different areas, and (b) had completed undergraduate studies in the previous $31 / 2$ years (42 months).

Analyses

An exploratory factor analysis (EFA) was first conducted to assess the underlying factor structure and refine the item pool. Second, a confirmatory factor analysis (CFA) was performed for testing UWS in a second-order model. In this way, combining EFA and CFA in the same sample allows for a more comprehensive assessment of the instrument's properties (Hurley et al., 1997).

First the EFA was conducted as a pretest to evaluate the questionnaire items and test if the construct dimensions would be reflected in the items' loading. Subsequently, the scales were modified based on the EFA results and then CFA was performed to 
check if the items and factors in question could be explained by a second-order factor (UWS). Finally, the instrument was re-specified based on the findings from the CFA.

After the instrument was fine-tuned, benefiting from the insights provided by the findings of both the EFA and CFA we conducted a validation test with an independent sample (see Stage 3, below).

In the EFA, the factors were extracted using the Principal Components method (PCA) with oblique rotation (Direct Oblimim). PCA is recommended when the goal is to reduce a large number of items to relatively few components (Costello and Osborne, 2005). Oblique rotation was used because it is the most appropriate method for social science research when the factors are believed to be correlated (Beavers et al., 2013).

For the CFA, the Maximum Likelihood (ML) method was used to estimate model parameters. The initial fit of this model was assessed and subjected to respecification depending on item error covariance estimates and modification indices. Model fit was assessed by the ratio of chi-square to degrees of freedom ( $\left.\mathrm{X}^{2} / \mathrm{df}\right)$, Comparative Fit Index (CFI), Parsimony Indices (GFI), and Root Mean Square Error Approximation (RMSEA), while Akaike Information Criterion (AIC), Bayes Information Criterion (BIC) and Browne-Cudeck Criterion (BCC) were used for model comparison. RMSEA values less than .08; CFI and GFI values greater than .90 and $\mathrm{X}^{2} / \mathrm{df}$ values between 1.0 and 2.0 indicate a good fitting model (Arbuckle, 2013).

Data analyses were conducted with IBM SPSS statistics (ver. 22), including AMOS for confirmatory factor analysis.

\section{Results}

Exploratory Factor Analysis (EFA) - For this sample the Kaiser-Meyer-Olkin (KMO) criterion was 0.92 and Bartlett's test of sphericity was significant $\left[\mathrm{X}^{2}(\mathrm{df}=465)\right.$ $=3918.689, \mathrm{p}<.001]$ indicating that correlations between UWSS items were sufficient 
to perform the factor analysis (Tabachnick and Fidell, 2013). Missing data were replaced by the mean substitution because they occurred on fewer than $5 \%$ of cases and their distribution was random (Horton and Kleinman, 2007).

Examination of the screeplot suggested that five factors with eigenvalues $>1$. Moreover, analysis of the correlation matrix showed that factor five had low correlations $(r \mathrm{~s}<.20)$ with the other four factors and items were cross-loadings in other factors. Due so factor five did not make possible a clear interpretation of it is nature.

Grounded on Beavers et al. (2013) and Hinkin (1998), items loadings less than .40 and with cross-loadings were deleted in order to keep a measure short and minimizing response biases caused by boredom or fatigue. Based on these criteria, five items were removed: 2, 10, 12, 20 and 24. Items and loadings from EFA are presented in Table 1.

insert Tables 1 and 2 about here

Next we repeated the EFA using the 26 remaining items. The Kaiser-MeyerOlkin $(\mathrm{KMO})$ was .90 and Bartlett's test of sphericity was significant $\left[\mathrm{X}^{2}(325)=\right.$ 3086.197, $\mathrm{p}<.001]$ indicating that the data were factorable (Tabachnick and Fidell, 2013). Examination of the screeplot suggested that four factors should be retained, all with eigenvalues $>1$.

Table 2 shows the items and associated factor loadings. As shown, all factor loadings were $>.40$. Together the four-factor solution accounted for $63.6 \%$ of the total variance and provided a parsimonious and simple factor structure that could be readily interpreted. The first factor was named 'career insertion and satisfaction' and contained seven items related to obtaining work in the same field as the degree completed and 
feelings of career satisfaction. The second factor, 'confidence in career future' comprised six items related to feelings of confidence and perseverance required to achieve career goals after graduation. The third factor, 'income and financial independence' was composed of eight items related to income and financial independence. Finally, the fourth factor, 'adaptation to work' included five items related to the adaptation to the demands of world of work and performance.

Confirmatory Factor Analysis (CFA) - The goal of the CFA was to test if a second-order model with a single higher-order factor, provided an adequate fit to the sample of 182 new graduates. The UWS second-order model with four-factors and 26 items yielded fit indices that were initially below recommended standards $\left(\mathrm{X}^{2} /(295)=864,910, \mathrm{p}<.001, \mathrm{~N}=182 ; \mathrm{X}^{2} / \mathrm{df}=2.93 ; \mathrm{CFI}=.806 ; \mathrm{GFI}=.73 ; \quad \mathrm{RMSEA}=\right.$ $0.103)$. These results indicated that the hypothesized model needed to be re-specified to provide a better fit to the sample data. Modification indices (MI) were examined in order to improve the model. These suggested that items 1 and $3(\mathrm{MI}=53.79), 9$ and 18 $(\mathrm{MI}=31.74)$ and 11 and $19(\mathrm{MI}=31.83)$ had high residual covariances. Additionally, modification indices suggested that items 14, 27 and 30 cross-loaded on more than one factor. After consideration of the item content and relevance for the theoretical framework, we decided to eliminate four items due to different reasons. We eliminated Item 3 ("I got a job in the same field of my degree") because it was redundant with item 1 ("I am working in the same field of my degree"). Items 14 ("I am satisfied with my job"), 27 ("I have succeed in achieving the goals I have planned for my career") and 30 ("I get into the world of work") were deleted because they had higher cross-loadings that were not clearly interpretable.

After the elimination of four items our model with 22 items showed a better fit indices $\quad\left(\mathrm{X}^{2} /(205)=454,82, \quad \mathrm{p}<.001, \quad \mathrm{~N}=182 ; \mathrm{X}^{2} / \mathrm{df}=2.21 ; \quad \mathrm{CFI}=.886 ; \quad \mathrm{GFI}=.81\right.$; 
RMSEA=.082). Additionally, owing to semantic relatedness between items 9 ("I am financially independent from my family") and 18 ["I am able to live by myself (out of my parents' house)"], and between items 11 ("I get remuneration compatible with the labor market in my area") and 19 ("I get a good pay compared to professionals in my field") we decided to included residual covariance among these similar but not redundant items (Mueller and Hancock, 2008).

The re-specified second-order model with 22 items is shown in Figure 1. The goodness-of-fit statistics were $\quad\left(X^{2} /(203)=392.34, \quad \mathrm{p}<.001, \quad \mathrm{~N}=182 ; \quad \mathrm{X}^{2} / \mathrm{df}=1.93\right.$; $\mathrm{CFI}=.914 ; \mathrm{GFI}=.83$; RMSEA $=.072$ ) and all fit indices improved compared to the initial CFA, and met recommended standards. Thus, results suggested that the re-specified model provided a reasonably good fit to the sample data.

insert Figure 1 about here

\section{Stage 3: Model comparison and evidence for reliability and convergent validity}

In Stage 3 we attempted to replicate the psychometric characteristics of the original sample through a cross-validation procedure. The second-order model from Stage 2 was tested with an independent sample and compared with other alternative models. Also, we checked the reliability of the scale and convergent validity.

\section{Method}

\section{Participants}

The sample for Stage 3 included 195 new graduates from public (66.2\%) and private (34.8\%) universities in Brazil, different from those in Stage 2. Of these, $65.1 \%$ were female and $34.9 \%$ male. Ages ranged from 21 to 61 years old $(\mathrm{M}=26.9 ; \mathrm{SD}=6.6)$. Regarding ethnicity, $79.5 \%$ of participants were Caucasian; $19.4 \%$ Black; and $1.0 \%$ 
Asian. Concerning the time to finish undergraduate studies, 55.4\% had completed their studies in a range of $6-17$ months, $42.1 \%$ between $18-29$ months, and $2.6 \%$ between 30 42 months. In terms of degree major, $14.4 \%$ had graduated in Business, $18.5 \%$ in Accounting, $22.6 \%$ in Law, $10.3 \%$ in Letters, $17.9 \%$ in Education and $16.4 \%$ in Psychology.

Procedures

The process for data collection was similar to the process conducted in Stage 2. The questionnaire was placed online and participants were directed to a URL link via email or Facebook.

Analyses

The first step was to run the CFA to compare the fits of the UWSS and two alternative models. Internal reliability was assessed by Cronbach's alpha. To examine convergent validity, correlations between the four factors of UWSS (career insertion and satisfaction, confidence in career future, income and financial independence and adaptation to work) and self-reported measure of salary were calculated. We predicted that salary would be positively related to extrinsic career outcomes.

Data analyses were conducted with IBM SPSS statistics (ver. 22), including AMOS for confirmatory factor analysis.

\section{Results}

After preliminary scale testing and modification, we conducted a crossvalidation study with an independent sample. Based on Hinkin's (1998) recommendations, in this stage the purpose of CFA was to assess the goodness-of-fit of our model compared to a single common factor model, and with a multi-trait model with the number of factors equal to the number of constructs in the new measure. Thus, CFA was first run for a one-factor solution in which all 22 items loaded onto a single 
factor (Model A) and subsequently run for the first order model with four factors (Model B). Finally, we tested the second-order model suggested by Stage 2 (Model C).

Table 3 provides a detailed summary of outcomes of statistical tests in which the models were compared. The fit indices for Model A (one factor solution) were below recommended standards. However, Models B and C provided an acceptable fit to the data. The first-order model with four factors (Model B) performed slightly better than the second-order model (Model C) across all indices. The difference in degrees of freedom (with second-order Model $\mathrm{C}$ being more complex) likely contributed to this result.

insert Tables 3 and 4 about here

Cronbach's alpha value for the overall scale (22 items) was .92. The alpha values for each of the four component factors ranged from .75 to .86 . This indicates that the scales had good internal consistency reliability.

Correlations among the UWSS variables and salary are presented in Table 4. As expected, all correlations among UWSS factors were higher than correlations between salary. Salary was significantly correlated only with 'income and financial independence' $(r=.31, \mathrm{p}<.001)$ indicating that this factor was related to an objective career success measure. Together these results provide some initial evidence that UWSS is a subjective career success measure that assesses personal evaluations of intrinsic and extrinsic career outcomes.

\section{Discussion}

Although there has been substantial research on career success there is a need to increase the range of construct operationalization and measurement because traditional 
measures do not reflect the diversity of careers (Abele et al., 2011; Dries, 2011; Heslin, 2005; Mulhall, 2011; Pan and Zhou, 2015). In the absence of an accepted frame to assess early career success, we looked to extant research in this area by developing a new and specific measure of university-to-work success that was cross-validated in two independent samples of new graduates in Brazil.

In Stage 1 we created a set of items that represents early career outcomes in new graduates' view and assessed their content validity. In Stage 2, the item pool was refined and an initial factor structure for the university-to-work success model was proposed. The factor analyses suggested a simplified version of UWSS with four factors that assess subjective perceptions of intrinsic and extrinsic career outcomes in the university-to-work transition. Also, results of Stage 2 supported the initial hypothesis that the four factors load on a single second-order factor. The university-to-work success model incorporated all four factors, and provides a simple, parsimonious and easily interpreted measure of early career success. In Stage 3, we used confirmatory factor analysis (CFA) to cross-validate the second-order model obtained in Stage 2 and to test this model against alternative models in an independent sample of new university graduates in Brazil. The CFA results indicated that fits for both first-order and the second-order model were reasonable. Correlations among variables suggested that the factor 'income and financial independence' reflect a perception of an extrinsic outcome and the other three factors (career insertion and satisfaction, confidence in career future and adaptation to work) assessed evaluations of intrinsic outcomes.

Comparing to earlier models of career success (Dyke and Murphy, 2006; Hennequin, 2007; Poon et al., 2015; Sturges, 1999), our model has some significant similarities. We found that early career success during university-to-work transition could also be described through perceptions of intrinsic and extrinsic career success 
measures such as career satisfaction, income and financial rewards. Although we recognize some similarities, our model identifies two novel intrinsic career success criteria associated with confidence in career future and adaptation to work that were not described before. UWSS items were generated based on new graduates' perceptions and speeches, and even those traditional outcomes reflect the special nature of early career success.

Despite the proposed model of university-to-work success was supported and appeared to have good validity, some limitations should be noted. First, the sample size, although adequate, was relatively small for a study of this type (Cabrera-Nguyen, 2010). Sampling used a convenience approach, in which participants were not identified randomly, but chosen, from different degree areas. Nevertheless, strength of the present study was that we validated results with a second, independent sample.

Another limitation was that the validated version of UWSS was not able to incorporate all eight factors envision in the initial theoretical model. Instead, results from Stage 2 suggested a model with four factors and 22 items, which loaded on a single higher-order factor named university-to-work success. Nevertheless, this model appears to have good face validity because its factors measure specific early career tasks such as career insertion, adaptation to work, confidence in career future, and financial independence (Russell, 2005). It is important to note that the development and validation of a new measure requires additional testing and systematic replication. This study provided the first test and the results indicated some direction for further refinement. Specifically, inclusion of additional items for the factor of "professional identity construction' may improve the model, because this may also be an important task during university-to-work transition. 
Additionally, the evaluation of construct validity for the UWSS is ongoing. Future research should examine convergent and discriminant validity by testing the extent to which the UWSS correlates with different measures of career success or by assessing the dissimilarities with variables that would not be expected to relate to career success, such as unemployment. Evaluation of differential validity could be assessed by exploring whether the use of the UWSS allows a distinction between university-to-work success on the basis of demographic variables such as gender, socioeconomic status, ethnicity and degree completed.

It is important also to acknowledge that the results presented here do not indicate our model is the only possible one for early career success during university-to-work transition. As with all individual studies, variables from the research context (e.g. culture, language, sample selection) have undoubtedly affected the model. Moreover, the study was conducted with samples of new university graduates in Brazil whose average age is usually higher than in other countries, and some had previous work experience (Ristoff, 2014). Generalization to different cultural contexts should not be assumed without further validation.

Despite these limitations, our study has some important implications. In theoretical terms, the university-to-work success model expands career success concepts by adding new criteria that are specific to early career stages. For new graduates' to feel successful in the university-to-work transition they must be able to work in the same field of their degree completed, pay their bills and live independently from their families. At the same time, they look for work experiences that are meaningful to them. Additionally, to be successful in this transition they must develop confidence and the ability to adapt to different work situations. These results are congruent with recent 
research on how young professionals approach their careers (Levit and Licina, 2011; Russell, 2005).

Our results suggest several directions for future research. University-to-work Success Scale might be employed to examine predictive or correlational relationships between early career success and other variables, such as career adaptability; career satisfaction, and career climbing. Furthermore, using a comprehensive university-towork success measure is advantageous because it provides a single measure relevant to assess perceptions of intrinsic and extrinsic early career outcomes. Consequently, it might facilitate testing of causal models and hypotheses using techniques of structural equation modeling.

In terms of practical implications, the results can be useful for practitioners in the field of career counselling and human resources management. It is known that college interventions and socialization programs can influence early career success (Koen et al., 2012; Langowitz et al., 2013). Career counselors and human resources professionals can help to plan different career interventions to better prepare new graduates making the transition to employment. Activities should focus on helping young professionals to develop self-management skills and also be more confident in their future, by creating and developing trust in themselves for dealing with their new social and professional tasks (Loureiro et al., 2013). In practical settings, the universityto-work success scale can be used as a tool for self-assessment or as an outcome measure to evaluate the efficacy of interventions.

In summary, the results of this study provide a useful instrument for better understanding how early career success is determined by the university-to-work transition. By providing a reliable and valid version of the UWSS, we hope that this new measure will contribute to future research and development in this area. 


\section{Acknowledgements}

This research was supported by CAPES Foundation, Ministry of Education of Brazil, through Sandwich-PhD Fellowship Program. Part of this research was conducted in partnership with School of Psychology, University of Minho, Portugal.

\section{References}

Abele, A.E. and Spurk, D. (2009), “The longitudinal impact of self-efficacy and career goals on objective and subjective career success", Journal of Vocational Behavior, Vol. 74 No. 1, pp. 53-62.

Abele, A.E., Spurk, D. and Volmer, J. (2011), "The construct of career success: measurement issues and an empirical example", Zeitschrift für Arbeitsmarktforschung, Vol. 43 No. 3, pp. 195-206.

Arbuckle, J.L. (2013), IBM, SPSS, AMOS Users'Guide, SPSS, Chicago, IL.

Arthur, M.B., Khapova, S.N. and Wilderom, C.P.M. (2005), "Career success in a boundaryless world", Journal of Organizational Behavior, Vol. 26 No. 2, pp. 177202.

Beavers, A.S., Lounsbury, J.W., Richards, J.K., Huck, S.W., Skolits, G.J. and Esquivel, S.L. (2013), "Practical considerations for using exploratory factor analysis in educational research", Practical Assessment Research \& Evaluation, Vol. 18 No. 6, pp. 1-13.

Boudreau, J.W., Boswell, W.R. and Judge, T.A. (2001), "Effects of personality on executive career success in the United States and Europe", Journal of Vocational Behavior, Vol. 58 No. 1, pp. 53-81. 
Cabrera-Nguyen, P. (2010), "Author guidelines for reporting scale development and validation results in the Journal of the Society for Social Work and Research", Journal of the Society for Social Work and Research, Vol. 1 No. 2, pp. 99-103.

Colakoglu, S.N. (2011), “The impact of career boundarylessness on subjective career success: the role of career competencies, career autonomy, and career insecurity", Journal of Vocational Behavior, Vol. 79 No. 1, pp. 47-59.

Costello, A.B. and Osborne, J.W. (2005), "Best practices in exploratory factor analysis: four recommendations for getting the most from your analysis", Practical Assessment Research \& Evaluation, Vol. 10 No. 7, pp. 1-9.

Converse, P.D., Pathak, J., DePaul-Haddock, A.M., Gotlib, T. and Merbedone, M. (2012), "Controling your environment and yourself: implications for career success", Journal of Vocational Behavior, Vol. 80 No. 1, pp. 148-159.

Day, R. and Allen, T.D. (2004), "The relationship between career motivation and selfefficacy with protégé career success", Journal of Vocational Behavior, Vol. 64 No. 1, pp. 72-91.

De Vos, A., De Clippeleer, I. and Dewilde, T. (2009), "Proactive career behaviors and career success during the early career", Journal of Occupational and Organizational Psychology, Vol. 82 No. 4, pp. 761-777.

De Vos, A., De Hauw, S. and Van der Heijden, B.I.J.M. (2011), "Competency development and career success: the mediating role of employability", Journal of Vocational Behavior, Vol. 79 No. 2, pp. 438-447.

Dries, N. (2011), “The meaning of career success: avoiding reification through a closer inspection of historical, cultural and ideological context", Career Development International, Vol. 16 No. 4, pp. 364-384. 
Dries, N., Pepermans, R. and Carlier, O. (2008), "Career success: constructing a multidimensional model”, Journal of Vocational Behavior, Vol. 73 No. 2, pp. 254-267.

Dries, N., Pepermans, R., Hofmans, J. and Rypens, L. (2009), "Development and validation of an objective intra-organizational career success measure for managers", Journal of Organizational Behavior, Vol. 30 No. 4, pp. 543-560.

Dyke, L.S. and Murphy, S.A. (2006), "How we define success: a qualitative study of what matters most to women and men", Sex Roles: A Journal of Research, Vol. 55 No. 5, pp. 357-372.

Gerber, T. and Saiki, D. (2010), "Success according to professionals in the fashion industry", The Career Develonment Ouarterlv, Vol. 58 No. 3, pp. 219-229.

Greenhaus, J.H., Parasuraman, S. and Wormley, W.M. (1990), "Effects of race on organizational experiences, job performance evaluations, and career outcomes", Academy of Management Journal, Vol. 33 No. 1, pp. 64-86.

Hall, D.T. and Chandler, D.E. (2005), "Psychological success: when the career is a calling", Journal of Organizational Behavior, Vol. 26 No. 2, pp. 155-176.

Hay, A. and Hodgkinson, M. (2006), "Exploring MBA career success", Career Development International, Vol. 11 No. 2, pp. 108-124.

Haro, J.-M., Castejón, J.-L. and Gilar, R. (2013), “General mental ability as moderator of personality traits as predictors of early career success", Journal of Vocational Behavior, Vol. 83 No. 2, pp. 171-180.

Hennequin, E. (2007), "What 'career success' means to blue-collar workers", Career Development International, Vol. 12 No. 6, pp. 565-581.

Heslin, P.A. (2003), "Self- and other-referent criteria of career success". Journal of Career Assessment, Vol. 11 No. 3, pp. 262-286. 
Heslin, P.A. (2005), "Conceptualizing and evaluating career success". Journal of Organizational Behavior, Vol. 26 No. 2, pp. 113-136.

Hinkin, T.R. (1998), "A brief tutorial on the development of measures for use in survey questionary", Organizational Research Methods, Vol. 1 No. 1, pp. 104-121.

Horton, N.J. and Kleinman, K.P. (2007), "Much ado about nothing: a comparison of missing data methods and software to fit incomplete data regression models", The American Statistician, Vol. 61 No. 1, pp. 79-90.

Hurley, A.E., Scandura, T.A., Schriesheim, C.A, Brannick, M.T., Seers, A., Vandenberg, R.J., et al. (1997), "Exploratory and confirmatory factor analysis: guidelines, issues, and alternatives”, Journal of Organizational Behavior, Vol. 18 No. 6, pp. 667-683.

Judge, T.A., Higgins, C.A., Thoresen, C.J. and Barrik, M.R. (1999), "The big five personality traits, general mental ability, and career success across the life span", Personnel Psychology, Vol. 52 No. 3, pp. 621-652.

Johnson, C.D. and Eby, L.T. (2011), "Evaluating career success of African American males: it's what you know and who you are the matters", Journal of Vocational Behavior, Vol. 79 No. 3, pp. 699-709.

Koen, J., Klehe, U. and Van Vianen, A.E.M. (2012), “Training career adaptability to facilitate a successful school-to-work transition”, Journal of Vocational Behavior, Vol. 81 No. 3, pp. 395-408.

Koivisto, P., Vuori, J. and Nykyri, E. (2007), "Effects of the school-to-work group method among young people”, Journal of Vocational Behavior, Vol. 70 No. 2, pp. 277-296. 
Langowitz, N.S., Allen, I.E. and Godwyn, M. (2013), "Early-career outcomes and gender: can educational interventions make a difference?", Gender in Management: An International Journal, Vol. 28 No. 2, pp. 111-134.

Levit, A. and Licina, S. (2011), "How the recession shaped millennial and hiring manager attitudes about millennials' future careers", Commissioned by Career Advisory Board, presented by DeVry University, available at: http://newsroom.devry.edu/images/20004/Future\%20of\%20Millennial\%20Career s\%20Report.pdf (accessed 6 June 2015).

Lewis, M. (1995), "Focus group interviews in qualitative research: a review of the literature", Action Research Electronic Reader, available at: http://www.scu.edu.au/schools/g cm/ar/arhome.html (accessed 6 June 2015).

Loureiro, M.N., Taveira, M.C. and Faria, L. (2013), "Career intervention for selfmanagement and entrepreneurship", International Journal of Management Science and Information Technology, Vol. 7 No. 7, pp. 34-48.

Mueller, R.O. and Hancock, G.R. (2008), "Best practices in structural equation modeling", in Osborne, J.W. (Ed.), Best Practices in Quantitative Methods, Sage, Thousand Oaks, CA, pp. 488-508.

Mulhall, S. (2011), “CSI: career success investigation”, Irish Journal of Management, Vol. 30 No. 2, pp. 67-93.

Nabi, G.R (1999), "An investigation into the differential profile of predictors of objective and subjective career success", Career Development International, Vol. 4 No. 4 , pp. 212-224.

Nabi, G.R. (2001), “The relationship between HRM, social support, and subjective career success among men and women”, International Journal of Manpower, Vol. 22 No. 5, pp. 457-474. 
Ng, T.W.H. and Feldman, D.C. (2007), “The school-to-work transition: a role identity perspective", Journal of Vocational Behavior, Vol. 71 No. 1, pp. 114-134.

Ng, T.W.H. and Feldman, D.C. (2014), "Subjective career success: a meta-analytic review", Journal of Vocational Behavior, Vol. 85 No.2, pp. 169-179.

Pan, J. and Zhou, W. (2015), "How do employees construe their career success: an improved measure of subjective career success", International Journal of Selection and Assessment, Vol. 23 No. 1, pp. 45-58.

Poon, J.M.L., Briscoe, J.P., Abdul-Ghani, R. and Jones, E.A. (2015), "Meaning and determinants of career success: a Malaysian perspective", Journal of Work and Organizational Psychology, Vol. 31 No. 1, pp. 21-29.

Potter, J. and Wetherell, M. (1987), Discourse and Social Psychology: Beyond Attitudes and Behavior, Sage, London, UK.

Ristoff, D. (2014), "The new profile of the Brazilian campus: an analysis of the socioeconomic profile of undergraduate students", Avaliação, Vol. 19 No. 3, pp. 723-747.

Russell, E.A. (2005), "Work performance and careers", in Brown, S.D. and Lent, R.W. (Eds.), Career Development and Counseling: Putting Theory and Research to Work, John Wiley \& Sons, Hoboken, NJ, pp. 203-224.

Sauer, S., Desmond, S. and Heintzelman, M. (2013), "Beyond the playing field: the role of athletic participation in early career success", Personnel Review, Vol. 42 No. 6, pp. 644-661.

Seibert, S.E. and Kraimer, M.L. (2001), "The five-factor model of personality and career success", Journal of Vocational Behavior, Vol. 58 No. 1, pp. 1-21.

Shaw, L. (2013), “Are we ready to address the new expectations of work and workers in the transforming world of work?" Work, Vol. 44 No. 1, pp. 3-9. 
Spurk, D. and Abele, A.E. (2014), "Synchronous and time-lagged effects between occupational self-efficacy and objective and subjective career success: findings from a four-wave and 9-year longitudinal study", Journal of Vocational Behavior, Vol. 84 No. 2, pp. 119-132.

Stumpf, S.A. (2014), "A longitudinal study of career success, embeddedness and mobility of early career professionals", Journal of Vocational Behavior, Vol. 85 No. 2, pp. 180-190.

Sturges, J. (1999), "What it means to succeed: personal conceptions of career success held by male and female managers at different ages", British Journal of Management, Vol. 10 No. 3, pp. 239-252.

Tabachnick, B. and Fidell, L. (2013), Using Multivariate Statistics, 6th ed., Allyn and Bacon, Boston, MA.

Van Dierendonck, D. and Van der Gasst, E. (2013), "Goal orientation, academic competences and early career success", Career Development International, Vol. 18 No. 7, pp. 694-711.

Waldman, D.A. and Kobar, T. (2004), "Student assessment center performance in the prediction of early career success", Academy of Management Learning and Education, Vol. 3 No. 2, pp. 151-167.

Wetherell, M. and Potter, J. (1988), "Discourse analysis and the identification of interpretative repertories", in Antaki, C. (Ed.), Analyzing Everyday Explanation: A Casebook of Methods, Sage, London, UK, pp. 168-183.

Wu, P., Foo, M. and Turban, D.B. (2008), "The role of personality in relationship closeness, developer assistance and career success", Journal of Vocational Behavior, Vol. 73 No. 3, pp. 440-448. 
Table 1

Exploratory Factor Analyses of University-to-Work Success Scale (31 items)

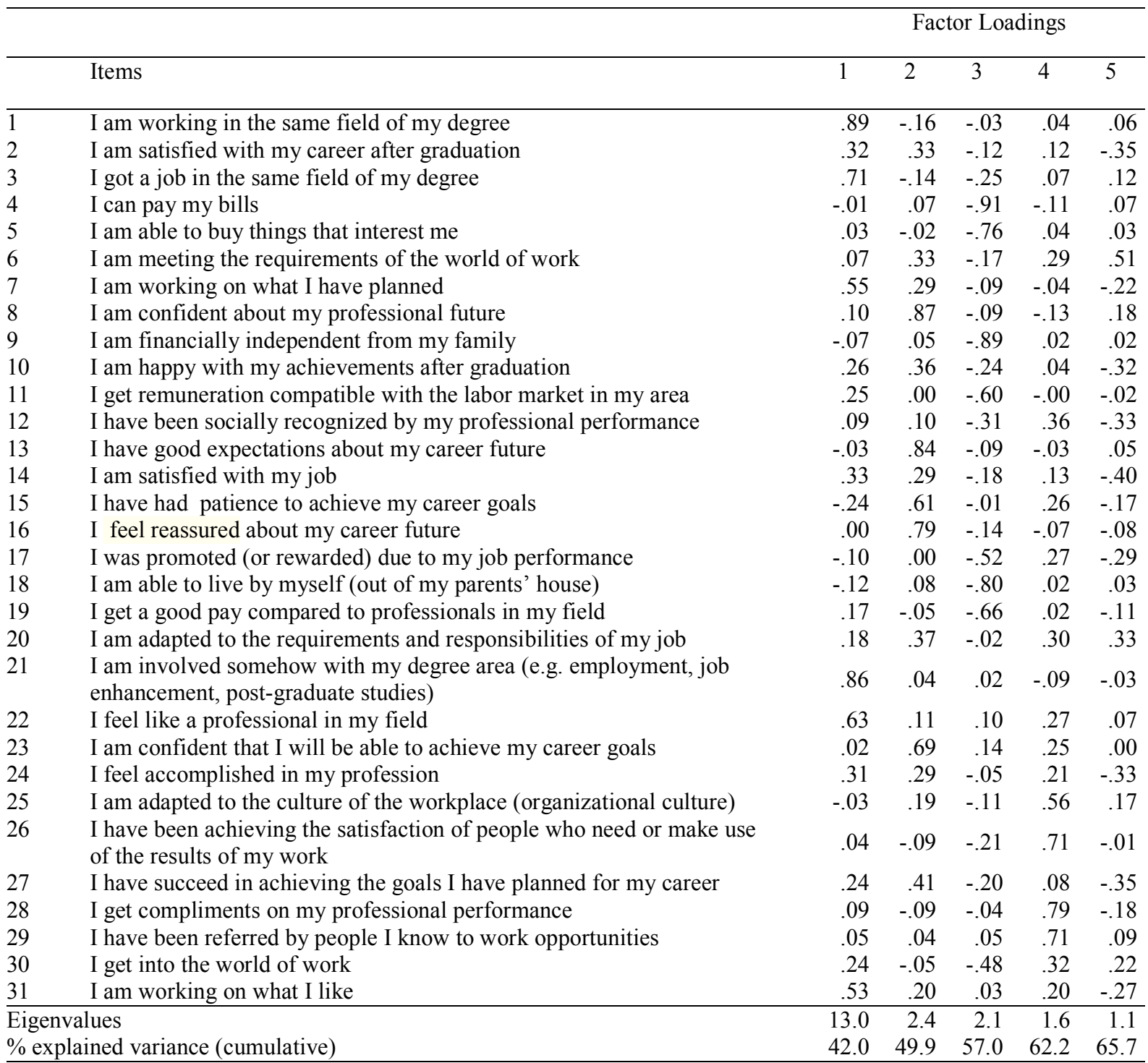


Table 2

Exploratory Factor Analyses of University-to-Work Success Scale (26 items)

\begin{tabular}{|c|c|c|c|c|}
\hline \multirow{2}{*}{$\begin{array}{l}\text { Factor name and items } \\
\text { Factor 1: Career Insertion and Satisfaction }\end{array}$} & \multicolumn{4}{|c|}{ Loadings } \\
\hline & 1 & 2 & 3 & 4 \\
\hline \#1 I am working in the same field of my degree & .84 & -.19 & -.01 & .15 \\
\hline \#3 I got a job in the same field of my degree & .66 & -.21 & -.21 & .22 \\
\hline \#7 I am working on what I have planned & .63 & .34 & -.13 & -.13 \\
\hline \#14 I am satisfied with my job & .47 & .41 & -.24 & -.05 \\
\hline $\begin{array}{l}\text { \#21 I am involved somehow with my degree area (eg. employment, job } \\
\text { enhancement, post-graduate studies) }\end{array}$ & .85 & .03 & .02 & -.04 \\
\hline \#22 I feel like a professional in my field & .58 & .05 & .11 & .38 \\
\hline \#31 I am working on what I like & .64 & .30 & -.02 & .04 \\
\hline \multicolumn{5}{|l|}{ Factor 2: Confidence in Career Future } \\
\hline \#8 I am confident about my professional future & .05 & .76 & -.03 & .06 \\
\hline \#13 I have good expectations about my career future & -.03 & .79 & -.06 & .07 \\
\hline \#15 I have had patience to achieve my career goals & -.14 & .67 & -.02 & .18 \\
\hline \#16 I feel reassured about my career future & .04 & .78 & -.13 & -.04 \\
\hline \#23 I am confident that I will be able to achieve my career goals & .05 & .69 & .14 & .28 \\
\hline \#27 I have succeed in achieving the goals I have planned for my career & .37 & .51 & -.25 & -.07 \\
\hline \multicolumn{5}{|l|}{ Factor 3: Income and Financial Independence } \\
\hline \#4 I can pay my bills & -.06 & .02 & -.91 & -.05 \\
\hline \#5 I am able to buy things that interest me & .00 & -.04 & -.76 & .08 \\
\hline \#9 I am financially independent from my family & -.08 & .02 & -.89 & .05 \\
\hline \#11 I get remuneration compatible with the labor market in my area & .24 & -.00 & -.59 & .02 \\
\hline \#17 I was promoted (or rewarded) due to my job performance & .03 & .14 & -.58 & .04 \\
\hline \#18 I am able to live by myself (out of my parents' house) & -.15 & .05 & -.82 & .05 \\
\hline \#19 I get a good pay compared to professionals in my field & .20 & -.02 & -.68 & -.02 \\
\hline \#30 I get into the world of work & .18 & -.10 & -.44 & .43 \\
\hline \multicolumn{5}{|l|}{ Factor 4: Adaptation to Work } \\
\hline \#6 I am meeting the requirements of the world of work & -.08 & .14 & -.03 & .60 \\
\hline \#25I am adapted to the culture of the workplace (organizational culture) & -.07 & .13 & -.11 & .63 \\
\hline $\begin{array}{l}\# 26 \text { I have been achieving the satisfaction of people who need or make use of } \\
\text { the results of my work }\end{array}$ & .09 & .01 & -.24 & .62 \\
\hline \#28I get compliments on my professional performance & .22 & .04 & -.09 & .58 \\
\hline \#29I have been referred by people I know to work opportunities & .08 & .07 & .05 & .68 \\
\hline Eigenvalues & 10.6 & 2.4 & 2.1 & 2.4 \\
\hline$\%$ explained variance (cumulative) & 40.9 & 50.1 & 58.2 & 63.6 \\
\hline
\end{tabular}


Table 3

Confirmatory factor analyses: comparison of model fit indices

\begin{tabular}{lccccccccc}
\hline Model & $\mathrm{X}^{2}$ & $\mathrm{df}$ & $\mathrm{CMIN} / \mathrm{df}$ & $\mathrm{CFI}$ & GFI & RMSEA & AIC & BIC & BCC \\
\hline $\begin{array}{l}\text { Model A: one } \\
\text { factor solution }\end{array}$ & 926.22 & 207 & 4.47 & .666 & .662 & .134 & 1018.22 & 1168.78 & 1030.59 \\
$\begin{array}{l}\text { Model B: first } \\
\text { order model }-\end{array}$ & 440.74 & 201 & 2.19 & .889 & .834 & .078 & 544.74 & 714.93 & 558.72 \\
four factors & & & & & & & & & \\
$\begin{array}{l}\text { Model C: } \\
\begin{array}{l}\text { Second-order } \\
\text { model (Stage 2) }\end{array}\end{array}$ & 453.22 & 203 & 2.23 & .884 & .829 & .080 & 553.22 & 716.874 & 566.67 \\
\hline
\end{tabular}

Table 4

Correlations among study variables for Stage 3

\begin{tabular}{|c|c|c|c|c|c|}
\hline Variables & CIS & $\mathrm{CCF}$ & IFI & WA & SAL \\
\hline Career Insertion and Satisfaction (CIS) & 1 & & & & \\
\hline Confidence in Career Future (CCF) & $.57^{* *}$ & 1 & & & \\
\hline Income and Financial Independence (IFI) & $.54^{* *}$ & $.45^{* *}$ & 1 & & \\
\hline Adaptation to Work (WA) & $.59^{* *}$ & $.55^{* *}$ & $.66^{* *}$ & 1 & \\
\hline Salary (SAL) & .12 & .12 & $.31^{* *}$ & .13 & 1 \\
\hline
\end{tabular}




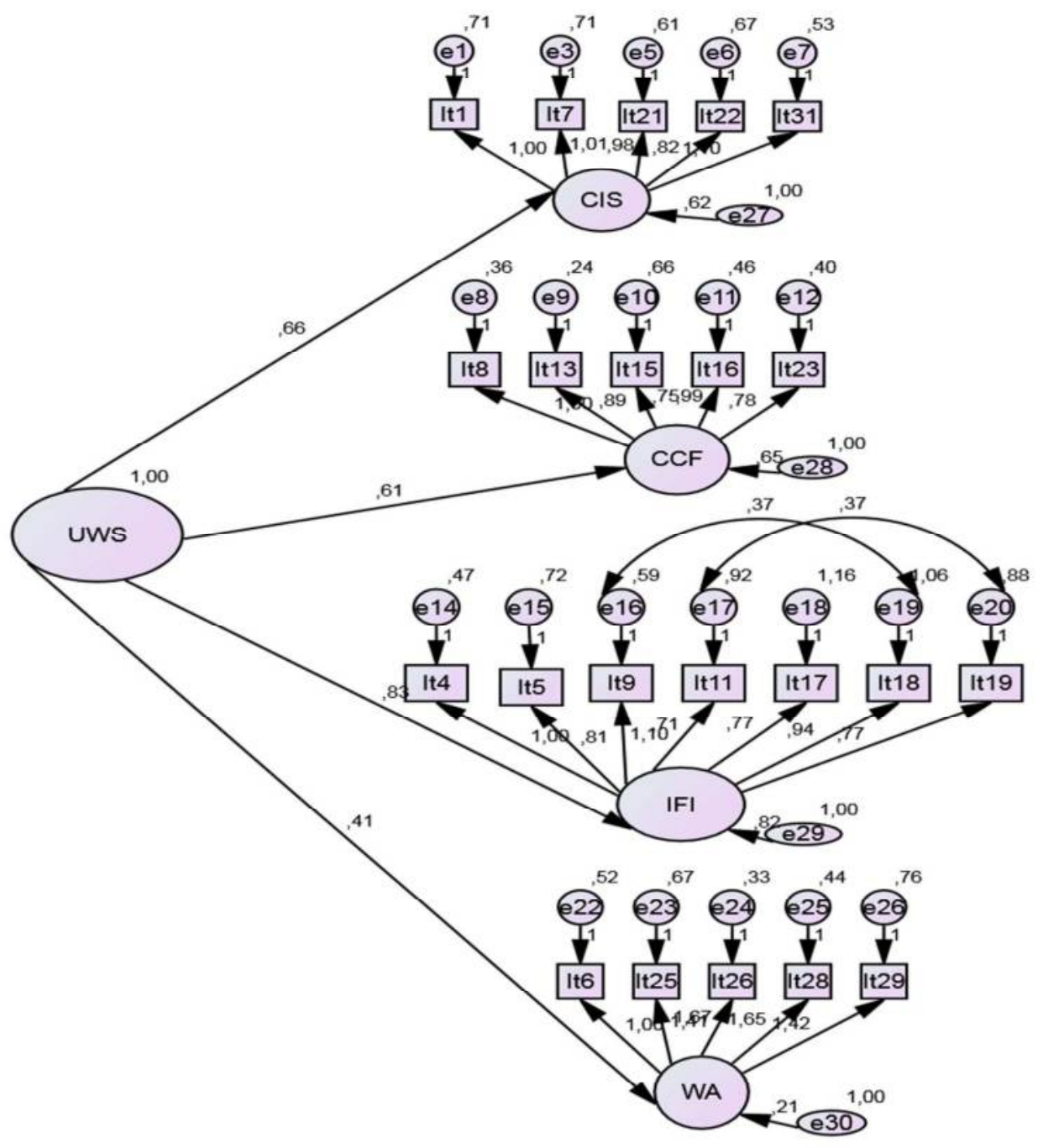

Figure 1: University-to-Work Success - Second-order Confirmatory Factor Analyses. $\mathrm{X}^{2} /(203)=392.34, \mathrm{p}<.001, \mathrm{~N}=182 ; \mathrm{X}^{2} / \mathrm{df}=1.93 ; \mathrm{CFI}=.914 ; \mathrm{GFI}=.83 ; \mathrm{RMSEA}=.072 ; \mathrm{AIC}=492.34 ;$ $\mathrm{BIC}=652.54 ; \mathrm{BCC}=506.90$. Note. University-to-Work Success (UWS); Career Insertion and Satisfaction (CIS); Confidence in Career Future (CCF); Income and Financial Independence (IFI); Adaptation to Work (WA). 


\section{Appendix}

\section{University-to-Work Success Scale (UWSS)}

(Portuguese and English versions)

Following you will find 22 items that depict some indicators of career success during university-towork transition. Please indicate the extent to which you agree with the statements below using a scale of 1 (do not agree at all) to 5 (agree entirely). Consider what you believe you have achieved after graduation.

\begin{tabular}{|c|c|c|}
\hline & Items & Dimension \\
\hline 1 & $\begin{array}{l}\text { Consegui um trabalho na minha área de formação } \\
\text { I am working in the same field of my degree }\end{array}$ & CIS \\
\hline 2 & $\begin{array}{l}\text { Consigo pagar as minhas contas } \\
\text { I can pay my bills }\end{array}$ & IFI \\
\hline 3 & $\begin{array}{l}\text { Tenho condições de comprar as coisas que me interessam } \\
\text { I am able to buy things that interest me }\end{array}$ & IFI \\
\hline 4 & $\begin{array}{l}\text { Estou adaptado às exigências do mundo do trabalho } \\
\text { I am meeting the requirements of the world of work }\end{array}$ & WA \\
\hline 5 & $\begin{array}{l}\text { Estou atuando profissionalmente naquilo que planejei } \\
\text { I am working on what I have planned }\end{array}$ & CIS \\
\hline 6 & $\begin{array}{l}\text { Estou confiante em relação ao meu futuro profissional } \\
\text { I am confident about my professional future }\end{array}$ & $\mathrm{CCF}$ \\
\hline 7 & $\begin{array}{l}\text { Sou independente financeiramente da minha familia } \\
\text { I am financially independent from my family }\end{array}$ & IFI \\
\hline 8 & $\begin{array}{l}\text { Recebo uma remuneração compativel com o mercado da minha área de formação } \\
\text { I get remuneration compatible with the labor market in my area }\end{array}$ & IFI \\
\hline 9 & $\begin{array}{l}\text { Tenho boas expetativas em relação ao meu futuro profissional } \\
\text { I have good expectations about my career future }\end{array}$ & $\mathrm{CCF}$ \\
\hline 10 & $\begin{array}{l}\text { Tenho tido paciência para conquistar meus objetivos de carreira } \\
\text { I have had patience to achieve my career goals }\end{array}$ & $\mathrm{CCF}$ \\
\hline 11 & $\begin{array}{l}\text { Estou tranquilo em relação ao meu futuro profissional } \\
\text { I fell reassured about my career future }\end{array}$ & $\mathrm{CCF}$ \\
\hline 12 & $\begin{array}{l}\text { Fui promovido (ou premiado) pelo meu desempenho profissional } \\
\text { I was promoted (or rewarded) due to my job performance }\end{array}$ & IFI \\
\hline 13 & $\begin{array}{l}\text { Tenho condições de morar sozinho (sair da casa dos meus pais) } \\
\text { I am able to live by myself (out of my parents' house) }\end{array}$ & IFI \\
\hline 14 & $\begin{array}{l}\text { Recebo uma boa remuneração quando comparada aos profissionais da minha } \\
\text { área } \\
\text { I get a good pay compared to professionals in my field }\end{array}$ & IFI \\
\hline 15 & $\begin{array}{l}\text { Consegui me vincular de alguma maneira com a minha área de formação (ex.: } \\
\text { emprego, trabalho, aprimoramento, pós-graduação) } \\
\text { I am involved somehow with my degree area (e.g. employment, job enhancement, } \\
\text { post-graduate studies) }\end{array}$ & CIS \\
\hline 16 & $\begin{array}{l}\text { Sinto-me um profissional na minha área } \\
\text { I feel like a professional in my field }\end{array}$ & CIS \\
\hline 17 & $\begin{array}{l}\text { Estou confiante que irei conseguir atingir os meus objetivos na carreira que escolhi } \\
\text { I am confident that I will be able to achieve my career goals }\end{array}$ & $\mathrm{CCF}$ \\
\hline 18 & $\begin{array}{l}\text { Estou adaptado à cultura do mundo do trabalho (organizacional) } \\
\text { I am adapted to the culture of the workplace (organizational culture) }\end{array}$ & WA \\
\hline 19 & $\begin{array}{l}\text { Tenho conquistado a satisfação das pessoas que precisam ou fazem uso dos resultados } \\
\text { do meu trabalho } \\
\text { I have been achieving the satisfaction of people who need or make use of the } \\
\text { results of my work }\end{array}$ & WA \\
\hline 20 & $\begin{array}{l}\text { Recebo elogios pelo meu desempenho profissional } \\
\text { I get compliments on my professional performance }\end{array}$ & WA \\
\hline 21 & $\begin{array}{l}\text { Tenho sido indicado por pessoas que conheço para oportunidades de trabalho } \\
\text { I have been referred by people I know to work opportunities }\end{array}$ & WA \\
\hline 22 & $\begin{array}{l}\text { Estou trabalhando naquilo que eu gosto } \\
\text { I am working on what I like }\end{array}$ & CIS \\
\hline
\end{tabular}

Note: Career Insertion and Satisfaction (CIS); Income and Financial Independence (IFI); Adaptation to Work (WA); Confidence in Career Future (CCF) 


\section{Author Details}

Marina Cardoso de Oliveira is a professor of work and organizational psychology and career counseling at the Federal University of Triângulo Mineiro, Brazil. She received her $\mathrm{PhD}$ in Science/Psychology from University of São Paulo. Her research interests include career success, university-to-work transition and instrument development. Her research has been published in journals such as Brazilian Journal of Vocational Guidance and Psychological Assessment.

Lucy Leal Melo-Silva is a professor at the undergraduate and the graduate program in Psychology, at the Faculty of Philosophy, Sciences and Letters at Ribeirão Preto, University of São Paulo, Brazil (FFCLRP-USP). Her research interests are in the area of Vocational Guidance and Careers. Publisher of the Brazilian Journal of Vocational Guidance, and author of books in the field of Career Guidance and Training in Psychology, CNPq address to access the Curriculum Vitae: http://lattes cnpq.br/1041574665110656.

Maria do Céu Taveira is a professor of career development and counseling at the School of Psychology of University of Minho, Portugal. She received her PHD in Educational Psychology from University of Minho, Portugal. Her research interests include career exploration, career adjustment, and career intervention efficacy. Her research has been published in journals such as Journal of Vocational Behavior, Educational Review and Social Indicators Research.

Randolph C. Grace is professor of psychology at the University of Canterbury, Christchurch, New Zealand. He is a fellow of the American Psychological Association and a past President of the Society for the Quantitative Analyses of Behavior. He has published over 100 articles in a range of journals including Behavioral and Brain Sciences, Journal of Consulting and Clinical Psychology, Journal of Experimental Psychology: General, and Animal Cognition. 